\title{
NOTE
}

\section{Nematode parasites of commercially important fish in NW Spain}

\author{
M. L. Sanmartín Durán, P. Quinteiro, F. M. Ubeira \\ Departamento de Microbiologia y Parasitología, Cátedra de Parasitología, Facultad de Farmacía, Universidad de Santiago de Compostela, \\ Santiago, Spain
}

ABSTRACT: A study of the nematode parasites of 496 fish caught off NW Spain between December 1985 and March 1986 resulted in the identification of the following species: Proleptus obtusus (in $91.2 \%$ of Scyliorhinus canicula specimens); Cucullanus hians (in $31.8 \%$ of Conger conger); Cucullanus heterochrous (in $1 \%$ of Scophthalmus maximus); Cristitectus congeri (in $8.2 \%$ of C. conger); Anisakis simplex $\mathrm{L}_{3}$ (larvae Stage 3) (in $3.5 \%$ of S. canicula, $62.3 \%$ of Micromesistius poutassou, $25 \%$ of Zeus faber, $43.9 \%$ of Trachurus trachurus, $10.8 \%$ of Lepidorhombus wiffiagonis, $30.4 \%$ of $L$. boseii and $9.1 \%$ of $C$. conger); Hysterothylacium aduncum $\mathrm{L}_{3}$ (in $23.9 \%$ of $M$. poutassou, $14.3 \%$ of Trigla lucerna, $78.1 \%$ of Trachurus trachurus, $27.7 \%$ of $L$. wiffiagonis, $13 \%$ of $L$. boseii, $5.8 \%$ of Microchirus variegatus and $1.8 \%$ of $C$. conger) and $H$. aduncum (in $2.7 \%$ of $C$. conger and $10 \%$ of $S$. maximus).

In addition to its taxonomic interest, characterization of the helminth fauna of fish is of considerable importance from the point of view of hygiene and public health. There have, for example, been numerous reports of human anisakiosis resulting from the consumption of raw or undercooked fish (Chitwood 1970, Dailey et al. 1981). Though the larvae of the ascarids responsable for anisakiosis are found in almost all marine fish, the main source of human infection in Japan is the common mackerel Scomber japonicus, whereas in the USA it is smoked salmon (Oshima 1987). In continuance of our study of helminths in hosts of commercial importance off the coast of Galicia (NW Spain), we report here the prevalence and intensity of infections by nematodes.

Material and methods. We examined a total of 496 fish caught between 4 December 1985 and 1 March 1986 by boats fishing in the northeast Atlantic in the area $9^{\circ} 18^{\prime}$ to $9^{\circ} 34^{\prime} \mathrm{W}, 42^{\circ} 38^{\prime}$ to $42^{\circ} 50^{\prime} \mathrm{N}$. The fish were inmediately transported to the laboratory where they were examined under a stereomicroscope. Later they were carefully dissected for observation of the internal organs. Muscle was filleted to observe nematode larvae. In the case of mackerrel it was placed in digestion solution $(7 \mathrm{~g}$ pepsin powder $+5 \mathrm{ml} \mathrm{HCl}+950 \mathrm{ml} 0.9 \%$ $\mathrm{NaCl}$ ). Nematodes were killed and fixed with Berland's fluid or warm ethanol, stored in $70 \%$ alcohol, cleared in lactophenol, and mounted in Hoyer's fluid containing a small amount of Cotton Blue (which brings out cuticular structures).

Results and discussion. We identified 6 species of adult nematodes and 2 species of larvae belonging to the Physalopteridae, Cystidicolidae, Anisakidae and Cucullanidae. Table 1 lists the hosts examined, their infection rates, and the prevalence and intensity of infection of each host by its main nematode parasites. It is noteworthy that most of the nematodes found were the larval phase ascarids Hysterothylacium aduncum $\mathrm{L}_{3}$ and Anisakis simplex $\mathrm{L}_{3}$ which were most prevalent in Trachurus trachurus and Micromesistius poutassou respectively; numerous authors consider these to be the most common marine fish nematodes.

The Anisakis specimens where found to fit Berland's (1961) description of Anisakis Type I, which later authors (Pippy \& Banning 1974, Smith 1983) found to correspond to Anisakis simplex, whose geographical range covers cold zones (Kagei 1974). Anisakis was most prevalent among Micromesistius poutassou specimens, over $60 \%$ of which were infected, though this rate is slightly lower then that reported by Mackenzie (1979) for the north-east Atlantic off Scotland. None of our specimens exceeded $30 \mathrm{~cm}$ in length, and it is known that the prevalence and intensity of infection by Anisakis larvae increase with fish size (McGladery \& Burt 1985). In Trachurus trachurus we observed encysted Anisakis larvae in the body cavity and in some cases, in the flesh $(2.4 \%)$. In $M$. poutassou we observed postmortem migrations from the body cavity, but the larvae left the fish, piercing the skin, without encysting in the flesh. Smith (1984) found postmortem migrations of $A$. simplex $\mathrm{L}_{3}$ into the flesh of some fatty species (herring, mackerel) but not of non-fatty species 
Table 1. Parasite-host distribution data

\begin{tabular}{|c|c|c|c|c|c|}
\hline H Iost & No. examined & $\%$ Infected & Parasites & Prevalence & Intensity \\
\hline \multirow{2}{*}{ Scyliorhinus canicula } & 57 & $91 \%$ & Proleptus obtusus & $91.2 \%$ & 37.3 \\
\hline & & & Anisakis simplex $\mathrm{L}_{3}$ & $3.5 \%$ & 1.5 \\
\hline \multirow{2}{*}{ Micromesistius poutassaou } & 67 & $65.6 \%$ & Anisakis simplex $\mathrm{L}_{3}$ & $63.3 \%$ & 5.8 \\
\hline & & & Hysterothylacium aduncum $\mathrm{L}_{3}$ & $23.9 \%$ & 6.1 \\
\hline Trisopterus luscus & 4 & 0 & 0 & 0 & 0 \\
\hline Zeus faber & 4 & $25 \%$ & Anisakis simplex $\mathrm{L}_{3}$ & $25 \%$ & 1 \\
\hline Trigla lucerna & 14 & $14.3 \%$ & Hysterothylacium aduncum $\mathrm{L}_{3}$ & $14.3 \%$ & 4.5 \\
\hline \multirow[t]{2}{*}{ Trachurus trachurus } & 82 & $84.1 \%$ & Anisakis simplex $\mathrm{L}_{3}$ & $43.9 \%$ & 7.3 \\
\hline & & & Hysterothylacium aduncum $\mathrm{L}_{3}$ & $78 \%$ & 16.7 \\
\hline \multirow[t]{2}{*}{ Lepidorhombus whiffiagonis } & 65 & $35.4 \%$ & Anisakis simplex $\mathrm{L}_{3}$ & $1.0 .8 \%$ & 1.1 \\
\hline & & & Hysterothylacium aduncum $\mathrm{L}_{3}$ & $27.7 \%$ & 2.2 \\
\hline \multirow[t]{2}{*}{ Lepidorhombus boscii } & 23 & $30.4 \%$ & Anisakis simplex $\mathrm{L}_{3}$ & $30.4 \%$ & 3 \\
\hline & & & Hysterothylacium aduncum $\mathrm{L}_{3}$ & $13 \%$ & 3 \\
\hline \multirow{2}{*}{ Scophthalmus maximus } & 10 & $10 \%$ & Cucullanus heterochrous & $10 \%$ & 1 \\
\hline & & & Hysterothylacium aduncum & $10 \%$ & 1 \\
\hline Microchirus variegatus & 52 & $5.8 \%$ & Hysterothylacium aduncum $\mathrm{L}_{3}$ & $1 \%$ & 1 \\
\hline Solea lascaris & 9 & 0 & 0 & 0 & 0 \\
\hline \multirow[t]{5}{*}{ Conger conger } & 110 & $45.5 \%$ & Anisakis simplex $\mathrm{L}_{3}$ & $9 \%$ & 2 \\
\hline & & & Hysterothylacium aduncum $\mathrm{L}_{3}$ & $1.8 \%$ & 1 \\
\hline & & & Hysterothylacium aduncum & $2.7 \%$ & 2 \\
\hline & & & Cucullanus hians & $31.8 \%$ & 1.9 \\
\hline & & & Cristitectus congeri & $8.2 \%$ & 5.3 \\
\hline
\end{tabular}

(blue whiting, whiting, walleye pollock). McGladery (1986) has suggested that host feeding habits may be an important factor in the establishment of $A$. simplex $\mathrm{L}_{3}$ in flesh.

The Hysterothylacium aduncum larvae found in this study fit the descriptions given by Fagerholm (1982), Moravec \& Nagasawa (1985). They were most prevalent among Trachurus trachurus specimens $(78 \%$ in body cavity and $1.2 \%$ in muscle). According to Fagerholm (1982), whereas $H$. aduncum $\mathrm{L}_{3}$ is commonest in autumn and winter, the adult phase is most frequent in summer, which explains the low prevalence of adults recorded in Conger conger and Scophthalmus maximus, the $H$. aduncum hosts mentioned by Petter (1969).

The prevalence of Cucullanus hians in Conger conger was moderate to low, $32 \%$ as against the $58 \%$ observed in this host in the Mediterranean by Muñoz et al. (1988). Those found in our study were mature adults (the number of which diminished as winter advanced) together with a few larvae encysted in the intestinal wall. This suggests seasonal behaviour similar to that reported by Mackenzie \& Gibson (1970) for Cucullanus minutus and $C$. heterochrous.

There is hardly any literature on Christitectus congeri (Petter 1970, Quinteiro et al. 1989). The prevalence observed is low but it must be taken into account that the sampling was made in the winter

Acknowledgement. This work was supported by the Spanish CAICYT under Project 18/84.

\section{LITERATURE CITED}

Berland, B. (1961). Nematodes from some Norwegian marine fishes. Sarsia 2: 1-50

Chitwood, M. (1970). Nematodes of medical significance found in market fish. Am. J trop. Med. Hyg. 19 (4): $599-602$

Dailey, M. D., Jensen, L. A., Hill, B. W (1981). Larval anisakine roundworms of marine fishes from Southern and Central California, with comments on public health significance. Calif. Fish Game 67 (4): 240-245

Fagerholm, H. P. (1982). Parasites of fish in Finland VI Nematodes. Acta Acad. Abo. Ser. B. 40 (6): 1-128.

Kagei, N. (1974). Studies on anisakjd Nematoda (Anisakinae) (IV) Survey of Anisakis larvae in marine Crustacea. Bull. Inst. Publ. Health 23 (2): 65-71

Mackenzie, K. (1979). Some parasites and diseases of blue whiting Micromesitus poutasou (Risso) to the North and West of Scotland and the Faroe Islands. Scott; Fish. Res. Rep. 17: 1-14

MacKenzie, K., Gibson, D. I. (1970). Ecological studies of some parasites of plaice Pleuronectes platessa L. and flounder Platichthys flesus L. Aspects of fish parasitology. Symposia of the British Society for Parasitology Vol 8, p. 1-42

McGladery, S. E. (1986). Anisakis simplex (Nematoda Anisakidae) infection of the musculature and body cavity of Atlantic herring (Clupea harengus harengus). Can. J. Fish. aquat. Sci. 43: 1312-1317

McGladery, S. E., Burt, D. B. (1985). Potential of parasites for use as biological indicators of migration, feeding, and spawing behavior of northwestern Atlantic herring (Clupea harengus). Can. J. Fish. aquat. Sci. 42: $1957-1968$

Moravec, F., Nagasawa, K. (1986). New records of amphipods as intermediate hosts for salmonid nematode parasites in Japan. Folia Parasitol. (Prague) 33: 45-49

Muñoz, M. V., Fernández, J. P., Orts, M. E., Carbonell, E. 
(1988). Sobre algunos nematodos cucullanidos parásitos de Conger conger (L.) en aguas del litoral valenciano. Rev. Iber. Parasitol. 48 (3): 275-281

Oshima, I (1987). Anisakiasis - Is the Sushi Bar guilty? Parasitology Today 3 (2): 44-48

Petter, A. J. (1969). Enquête sur les nematodes des poissons de la région nantaise. Identification des larves d'ascarides parasitant les sardines (en rapport avec les granulomes éosinophiles observes chez l'homme dans la région) Ann. Parasit. Hum. Comp. 44 (5): 559-580

Petter, A. J. (1970). Quelques spirurides de poissons de la région nantaise. Ann. Parasit. Hum. Comp. 45 (1): 31-46

Pippy, J. H. C., Van Banning, P. (1974). Identification of Anisakis larva (I) as Anisakis simplex (Rudolphi, 1809) det

Responsible Subject Editor Professor W. Körting, Hannover, F.R. Germany
Krabbe, 1878 (Nematoda: Ascaridata). J. Fish. Res. Bd Can. 32 (I) : 29-32

Quinteiro, P., Fernandez, J. A., Sanmartin Durán, M. L. (1989). First description of the male and new data on the female of Cristitectus congeri Petter, 1970 (Nematoda: Cystidicolidae). Syst. Parasitol. (in press)

Smith, S. W. (1983). Anisakis simplex (Rudolphr, 1809) det Krabbe, 1878 (Nematoda: Ascaridoidea): morphology and morphometry of larvae from euphausinds and fish and a review of the life history and ecology. J. Helminth. 57: 205-224

Smith, S. W. (1984). The abundance of Anisakis simplex in the body-cavity and flesh of marine teleosts. Int. J. Parasit. 14 (5): $491-495$

Manuscript first received: May 21, 1989

Revised version accepted: July 3,1989 